\title{
A SYSTEMATIC LITERATURE REVIEW OF SUSTAINABLE URBAN PLANNING CHALLENGES ASSOCIATED WITH DEVELOPING COUNTRIES
}

\author{
A.F. Jooste ${ }^{1 *}$, I.H. de Kock ${ }^{1}$ \& J.K. Musango ${ }^{1}$
}

\section{ARTICLE INFO}

\section{Article details}

Presented at the $30^{\text {th }}$ annual conference of the Southern African Institute for Industrial Engineering (SAlIE), held from 30 September - 2 October 2019 in Port Elizabeth, South Africa

Available online $\quad 15$ Nov 2019

\section{Contact details}

Corresponding author

andre.jooste@gmail.com

Author affiliations

1 Department of Industrial

Engineering, Stellenbosch

University, South Africa

\# $\quad$ Author was enrolled for an MEng in the Department of Industrial Engineering, Stellenbosch University, South Africa

\section{DOI}

http://dx.doi.org/10.7166/30-3-2247

\section{ABSTRACT}

The purpose of this study is to uncover the most prominent challenges that urban planners face when tackling sustainable practices in developing countries. The time frame was set to after the 2012 Rio +20 global summit. Therefore, only articles that were produced from 1 January 2013 till 31 March 2019 were included, as they would have adhered to the contributions and protocols set forth at the largest UN Earth Summit conference. In this study, a review of the sustainable urban planning challenges was conducted. The challenges are then grouped into topics that align with the theme of the type of challenge. Finally, the challenges are analysed to identify the most well-known and disruptive challenges that restrict urban planners in developing countries.

\section{OPSOMMING}

Die doel van die studie is die identifikasie van die mees prominente uitdagings wat stad- en streeksbeplanners in ontwikkelende lande in die gesig staar, spesifiek met betrekking tot volhoubare praktyke. Die oorwegingstydperk is beperk tot na die 2012 Rio +20 wêreldberaad. Publikasies vanaf 1 Januarie 2013 tot 31 Maart 2019 was oorweeg, omdat hulle sou voldoen aan die bydrae en protokolle soos bepaal deur die grootste VN Wêreldberaad. 'n Hersiening van volhoubare stadsbeplanning uitdagings is van stapel gestuur en die uitdagings dan gegroepeer in belynde onderwerpe. Laastens is die uitdagings ontleed om sodoende die mees bekende en ontwrigtende uitdagings te identifiseer.

Urban planning is a very old profession. It arose when people began to gather together for practical reasons, bringing resources, security, and amenities closer to more people [1]. However, in the $21^{\text {st }}$ century, traditions have changed rapidly, and cities need to be resilient in the face of urbanisation and population growth. Sustainability is the buzz word that is constantly found in master city plans. But do city planners know what this entails? Do they understand how to balance the environment with the economic, social, and political ideals of the city to ensure a stable and resilient future?

There seems to be a lack of consensus among urban planning practitioners about how to implement sustainable practices in urban development [1]; [2]; [3]; [4]. This is a difficult task, and it is imperative to ensure that the negative aspects of unsustainable situations do not prevail into the next generation. With the exponential growth of technology, it is very important to use the potential benefits in the urban development landscape.

This study seeks to identify the urban planning challenges that arise when planners attempt to initiate sustainable principles. The study used a systematic literature review (SLR) - a structured process that gathers relevant research papers on a specific theme. The challenges related to sustainable urban planning were identified in relevant research papers and synthesised in a large table containing all these challenges. Finally, the pertinent challenges that disrupt urban planners from designing and managing cities sustainably were revealed. 
The first section of the study explains the process of following through a systematic literature review from review questions to how the information was extracted. Then there is a brief analysis of the challenges that appear most frequently, together with a synthesis of the findings that will be investigated. The study concludes by answering the review questions and discussing further research.

\section{SYSTEMATIC LITERATURE REVIEW}

An SLR is a procedurally rigorous examination of research results [5]. The beginning of the project starts with a foundation of knowledge. The difference between a typical literature review and an SLR is found in the fundamental approach. An SLR follows a method that is set out before the review begins, and contains several steps, including extraction and synthesis. The SLR begins with a Boolean search, which refers to sifting through a large database of research articles using a group of synonyms for the theme under review (see Table 1). Next, the SLR method scrutinises the new group of research papers to ensure their relevance to the intended theme. See Figure 2 for the SLR search flowchart. Thereafter, the sustainable urban planning challenges are extracted from each paper; this is discussed further in Section 3. Lastly, the challenges are synthesised by tallying the number of challenges in each topic and conclude the SLR.

\subsection{Literature review questions}

The research questions addressed by this study were:

1. What research topics on sustainable urban planning are being addressed?

2. How effective is the systematic literature review?

3. What are the limitations and biases of a systematic literature review?

The literature review questions are discussed in the conclusion.

\subsection{Search strategy}

The literature search process was conducted using the Scopus database. The sources searched using a search string are presented in Table 1.

Table 1: Systematic literature review search strategy

\begin{tabular}{|c|c|c|c|c|}
\hline Urban planning & \multirow{4}{*}{ AND/OR } & Challenges & \multirow{4}{*}{ AND/OR } & Sustainable development \\
\hline Urban design & & Problems & & Sustainability \\
\hline Urban form & & Solutions & & \\
\hline Urban development & & Opportunities & & \\
\hline
\end{tabular}

\subsection{Study selection criteria}

If there are too many research records to choose from, then the search can be reduced using the terms (i) Developing countries, (ii) Sub-Saharan Africa, and (iii) South Africa. Articles on these topics were included if they were published between 1 January 2013 and 31 March 2019. This is because Rio +20 was held from 20 to 22 June 2012 . Rio +20 was the biggest UN conference ever presented; the previous Earth summit having been held 10 years before. Therefore, articles are only included from the year following this event, with relevance to sustainable urban planning. This choice is further solidified with the number of articles produced thereafter. See Figure 1, which displays the number of documents published per year from the relevant research papers produced over the last ten years.

The following types of papers were excluded:

- Informal literature surveys (no references, no publication)

- Papers not subject to peer-review

- Older versions of multiple papers found in more than one journal

Figure 2 is the SLR search flowchart that includes the process of the SLR, when and why papers were excluded, and the number of papers at each step of exclusion. 


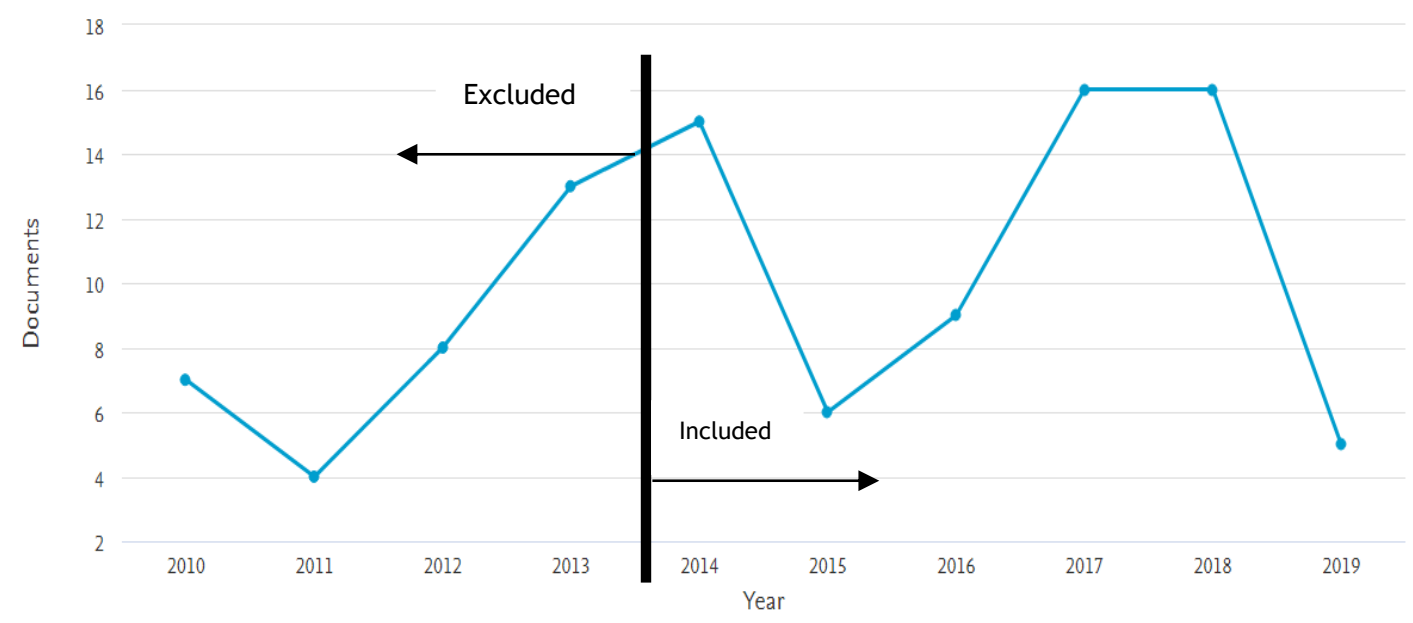

Figure 1: Number of documents published per year - (line of exclusion)

\subsection{Data extraction strategy}

The data extracted from each paper were:

- $\quad$ The name(s) of the author(s).

- The year when the paper was published. (Note, if the paper was published in several different sources, all dates were recorded, and the earliest date was used in the analysis.)

- $\quad$ To extract every challenge each paper mentions relating to sustainable urban planning.

- These challenges are referred to as a 'topic'. Main topics contain several subtopics that contribute and connect to each challenge.

- The topics are as follows: (i) sustainability, (ii) planning, (iii) urbanisation, (iv) urban sprawl, (v) society, (vi) environmental, (vii) economic, (viii) developing country, (ix) population growth, (x) government, (xi) energy, (xii) food security, and (xiii) climate change. These topics were found to be the most prevalent over the 41 research papers on sustainable urban planning.

\subsection{Synthesis of extracted data}

The sources were presented in a matrix, following the steps in section 2.4; articles falling into each topic and subtopic are totalled. Thereafter, a synthesis of the most discussed topics was drawn up.

\section{SYSTEMATIC LITERATURE REVIEW CHALLENGES}

With the use of a matrix containing all the challenges found in the 41 research papers selected in the SLR on sustainable urban planning, the most prevalent challenges that form most of a developing country's context were chosen. These dominant challenges were used to develop the links between current urban planning tools and techniques. This provided insight into the gap between current sustainable planning practice and the proposed future planning technique that was developed in this research project. In this section, the challenges contained in the SLR are discussed.

As mentioned in section 2.4, the challenges fall under 13 important topics. From this list, six topics have more than 50 challenges. Those are summarised in Table 2. 


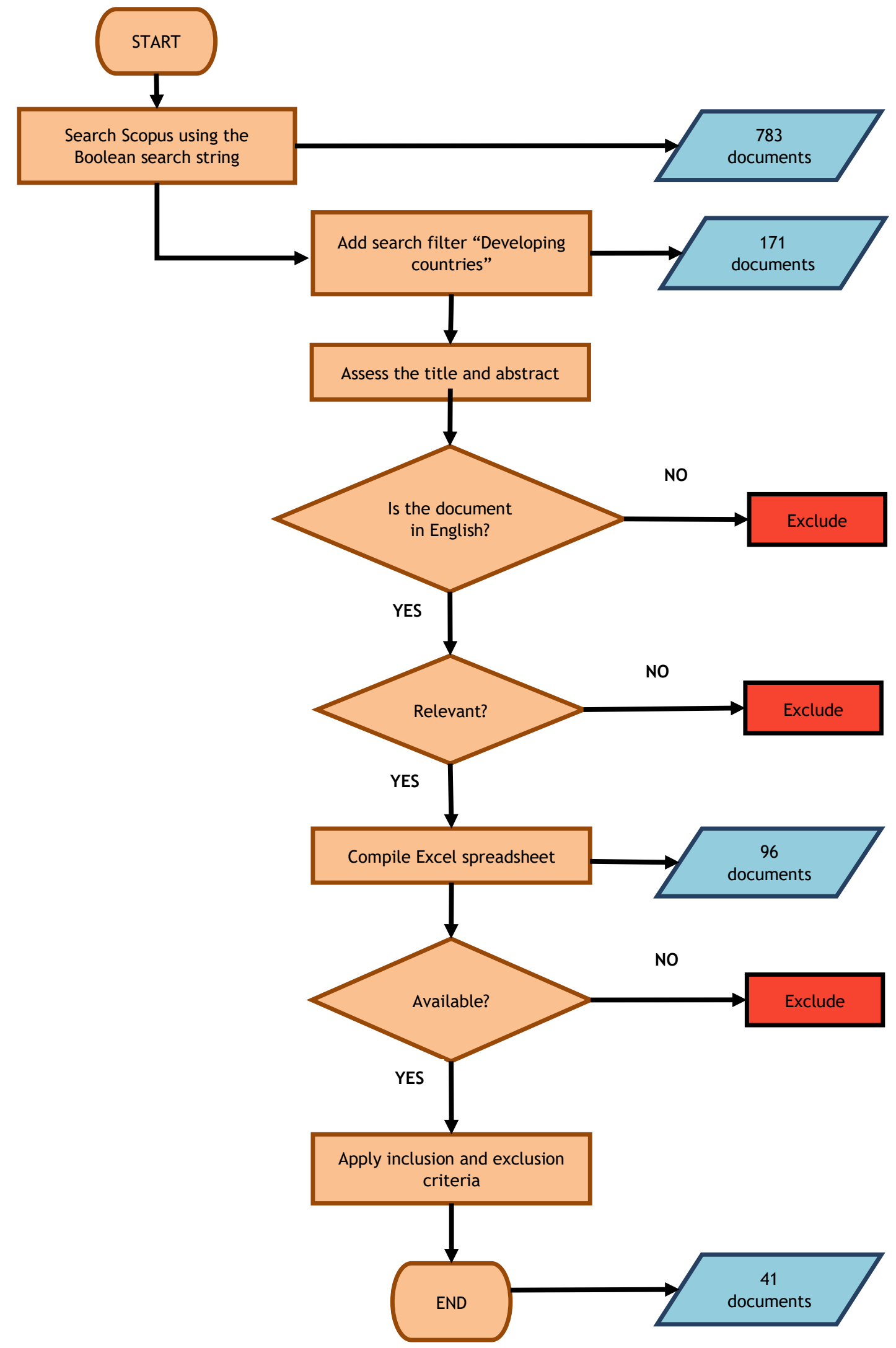

Figure 2: SLR search flowchart 
Table 2: Six main topics of the systematic literature review

\begin{tabular}{|l|c|c|}
\hline \multicolumn{1}{|c|}{ Main topic } & Overall total & Topic total \\
\hline Urban planning & 198 & 137 \\
\hline Sustainability & 115 & 46 \\
\hline Developing country & 90 & 55 \\
\hline Urbanisation & 88 & 70 \\
\hline Urban sprawl & 85 & 59 \\
\hline Population growth & 50 & 38 \\
\hline
\end{tabular}

The differences between the 'Overall total' column and the 'Topic total' column are where these challenges appeared. The 'Topic total' was found only under the specific topic in question. However, the 'Overall total' is where all the specific challenges were found throughout the matrix. For example, 'Overall total' contained the challenges found under any topic. If a challenge was also associated with an economic and urban planning issue, it was considered within the 'Overall total'.

There are 581 challenges in the SLR challenges matrix that were extracted from the 41 selected research articles. Furthermore, 34 per cent of the total challenges were about planning, while 20 per cent were linked to sustainability. From Table 2, it is evident that the total of all the main topic challenges adds up to 626. This is because the matrix is set up with each topic area containing topics to which the challenge is linked. Take, for example, the challenge that states, "Identifying a sustainable form of growth, especially when considering specific local context and conditions is a difficult task. Implementation of plans and the realisation of urban forms are even more challenging" [6]. This challenge is about the combination of sustainability and urban planning. Thus, it was placed under the main topic of sustainability and under the subtopic of urban planning. The reason for the overlaps was to show the links between all the topics and to allow for a greater synthesis of the challenges.

\subsection{Urban planning challenges}

The three prominent subtopics from the SLR that are found in urban planning are sustainability, society, and environment. Out of 137 challenges, 19,17, and 10 of those subtopics respectively were found only in the topic of urban planning and not overall, as seen in Table 2.

\subsubsection{Sustainability}

There is a lack of consensus about how to incorporate sustainable traditions into urban planning [1]; [2]; [3]; [4]. The challenges arise when trying to translate sustainability into city development. Planners have their own definitions and contexts that will disrupt any collaboration that may need to take place between policy coordinators, stakeholders, and government.

\subsubsection{Society}

Poor urban planning causes unwanted and spatially disjointed urban forms, leading to increased traffic congestion, vulnerability, and risks, and decreasing public health for the inhabitants in vulnerable areas [1]; [7]; [8]; [9]. Research reveals that planners do not realise the larger impact that their inconsistencies have on social dynamics in communities.

\subsubsection{Environment}

Urban planners seem to have the right intentions to protect the environment through designing cities and buildings. However, this has led to a contradictory outcome in which urban expansion has become unplanned, thus increasing carbon emissions and developing environmentally hazardous zones for residents [10]; [11]; [12]. Urban planners need to take more responsibility in realising their impact on the environment.

\subsection{Sustainability challenges}

The three prominent subtopics from the SLR that are found under 'sustainability' are urban planning, resource management, and environment. Out of 46 challenges, 11, four, and four of those subtopics respectively were found only in the topic of sustainability and not overall, as seen in Table 2.

\subsubsection{Urban planning}

Sustainable urban planning is imperative in today's city planning strategies. However, with everyone using the term, one would think that there would be a set definition to which everyone would adhere. However, "there is no agreement of sustainable urban forms" [13]. The confusion has led to the term 'sustainable urban planning' becoming distorted and impractical [8]. Even if one were 
to agree on a sustainable urban form for a specific context, there would still be little support from policy-makers and government to implement the practices [14]; [6].

\subsubsection{Resource management}

The essence of sustainability is to provide for future needs. A major concern is the depletion of resources such as energy, water, and food. "Natural resources should be seen as capital and not an income source" [15]. Critical analysis should be done to understand the stock of a city's resources, and venture to become a more self-sufficient system via circulation and limiting human activities [16]; [17]; [2].

\subsubsection{Environment}

Environmental conservation is rarely implemented into a nation's policy, as it is seen as antidevelopment, especially in developing countries, whose main goal is to be economic [14]; [8]; [18].

\subsection{Developing country challenges}

The three prominent subtopics from the SLR that are found in developing countries are economy, society, and urban planning. Out of 55 challenges, six, six, and five of those subtopics respectively were found only in the topic of developing country and not overall, as seen in Table 2.

\subsubsection{Economic}

Developing countries face many challenges to implement sustainable urban planning practices due to economic constraints [10]; [14]; [19]; [20]; [18]. Whether aligned with transport, water security, or enabling technological assistance, developing countries are falling further behind in applying sustainable projects.

\subsubsection{Society}

Developing countries face great challenges in the realm of social sustainability. A general definition of a developing country is one that is plagued with inequalities of income and quality of life, in which residents experience underemployment and inadequate shelter and living environments [16]; [21]; [20]. This is coupled with political systems that believe that all development is good if it provides jobs [18]. This statement does not follow sustainable practices: it is one-sided in following an economic path without taking the public's concerns for their wellbeing into account.

\subsubsection{Urban planning}

Urban planning in low- to middle-income countries cannot follow the development trends of developed countries due to the deep-rooted influences of uneven development caused by colonialism [22]. Furthermore, even if developing countries want to produce sustainable urban forms, they lack the infrastructure and management capabilities [23]; [10].

\subsection{Urbanisation challenges}

The three prominent subtopics from the SLR that are found in urbanisation are sustainability, society, and developing country. Out of 70 challenges, 14, 10, and nine of those subtopics respectively were found only in the topic of urbanisation and not overall, as seen in Table 2 .

\subsubsection{Sustainability}

Rapid urbanisation affects major issues such as resource consumption, environmental damage, economic and political changes, along with social problems; and so it is unsustainable in respect of urban planning [16]; [10]; [24]; [25]; [15]; [1]; [12].

\subsubsection{Society}

Urbanisation causes large disruptions from the perspective of social sustainability, producing social segregation, higher levels of pollution, unequal distribution of wealth, and poor public health systems [26]; [15]; [27]; [12]; [7].

\subsubsection{Developing country}

Urbanisation has a significant impact on developing countries, creating unplanned urban development, changing economy-oriented priorities for governments, threatening resource bases, and dictating fuel consumption patterns [26]; [17]; [25]; [28]; [15].

\subsection{Urban sprawl challenges}

The three prominent subtopics from the SLR that are found in urban sprawl are transportation, urban planning, and society. Out of 59 challenges, 11, 10, and nine of those subtopics respectively were found only in the topic of urban sprawl and not overall, as seen in Table 2. 


\subsubsection{Transportation}

"Sprawl, as a low-density and dispersed form of urban expansion, is generally considered to be a threat to sustainability: it is characterised by inefficient modes of transit" [6]. Sprawling development patterns cause auto-dependent societies: people are forced to travel long distances, spending up to 40 per cent of their income to get to work in town [21]; [29]; [30]; [31]; [7], further increasing carbon emissions and contributing to climate change.

\subsubsection{Urban planning}

Urban sprawl is a major problem for urban planners. It exists due to inadequate decision-making and management systems [1], leading to concerns about the availability of arable land for future generations' food security [32]; [2].

\subsubsection{Society}

Urban sprawl disrupts the social environments of communities on the peripheries of cities, reducing public health, and increasing unemployment and social segregation [4]; [6]; [1]; [7].

\subsection{Population growth}

The two prominent subtopics from the SLR that are found in population growth from the SLR are developing country and urban planning. Out of 38 challenges, 10 and five of those subtopics respectively were found only in the topic of population growth and not overall, as seen in Table 2.

\subsubsection{Developing country}

Worldwide population growth in future decades will be concentrated in developing countries [4]; [14]; [22]; [9]; [7]; [32].

\subsubsection{Urban planning}

With the unprecedented population growth occurring all over the globe, urban planners are struggling to keep up with all the infrastructural needs [19]; [3]; [24]; [33].

\section{SYNTHESIS OF SLR CHALLENGES}

Table 2 identifies the six most discussed topics that were found in the SLR. The topics that coincide with the search criteria are urban planning, sustainability, and developing country. Therefore, the topics that are of importance from the SLR are urbanisation, urban sprawl, and population growth. It is evident that these three phenomena are dependent on one another. For example, population growth leads to urbanisation as people need to survive, and cities have all the services and resources. This combination leads to rapid expansion, causing urban sprawl, along with all its negative impacts. To mitigate the problems caused by urban sprawl, urban planners need to resist these antidevelopment phenomena. Adaption methods and techniques must first be incorporated to manage the current issues. Then the new plans must develop a resilient structure to combat these changes as they arise. It is more important than ever for urban planners to use technology to predict these rapidly changing trends and to enhance the sustainability of cities in developing countries. It is known that developing countries lack data and specialised personnel. But, with this research, the hope is that a foundation can begin to be laid with the latest effective technology.

\section{CONCLUSION}

The research questions were formulated to ensure that the quality of the SLR was high. First, what were the research topics addressed? The SLR was framed around sustainable urban planning challenges in the context of developing countries. The topics that most clearly challenge urban planners were urbanisation, urban sprawl, and population growth. These topics are dependent on one another, and so need further investigation to identify the crux of the problem for sustainable practices in planning urban development. Second, how effective was the SLR? Forty-one research papers were found to be noteworthy for the SLR. All of the challenges addressed in this study came from 32 research papers. This reveals nine papers that described challenges that the majority were not discussing. This is not to say that the other nine were not considered. However, for the purpose of the SLR, the goal was to identify the most prominent challenges that have faced urban planners in the last seven years. The SLR was 78 per cent effective in identifying most of the challenges. Last, the SLR had limitations and biases. The first limitation was the time frame. Only gathering research papers since 2013 was a risk associated with this study. However, the Rio +20 conference was the defining event that influenced the research that followed. Figure 2 assists this argument, showing a large increase in research produced from 2013 onwards. The bias in the study emanates from the 
search criteria. The context of developing countries was a necessary focus for the study. Sustainable practices used in developed countries would be either too advanced or too expensive to allow developing nations to address their problems realistically.

The SLR discussed in this paper will be further implemented to uncover the tools and techniques used in current sustainable urban planning practices. Together with the synthesis in section 4 , a more structured approach will be identified for how to plan urban settings sustainably to ensure that future generations will not be left sorting out our problems.

\section{REFERENCES}

[1] Bibri, S.E. 2018. A foundational framework for smart sustainable city development: Theoretical, disciplinary, and discursive dimensions and their synergies. Sustainable Cities and Society, 38(September) pp. 758-794. doi: 10.1016/j.scs.2017.12.032.

[2] Gradinaru, S.R., Triboi, R., loja, C. \& Artmann, M. 2018. Contribution of agricultural activities to urban sustainability: Insights from pastoral practices in Bucharest and its peri-urban area. Habitat International, 82(September), pp. 62-71. doi: 10.1016/j.habitatint.2018.09.005.

[3] Mohareb, E., Derrible, S. \& Peiravian, F. 2016. Intersections of Jane Jacobs' conditions for diversity and low-carbon urban systems: A look at four global cities. Journal of Urban Planning and Development, 142(2), pp. 1-14. doi: 10.1061/(ASCE)UP.1943-5444.0000287.

[4] Shummadtayar, U., Hokao, K. \& lamtrakul, P. 2013. Investigating the low-income settlement in an urbanization and urban form a consequences of Bangkok growing city, Thailand. Lowland Technology International 15(1), pp. 45-54.

[5] Kitchenham, B. 2007. Guidelines for performing systematic literature reviews in software engineering. Software Engineering Group School of Computer Science and Mathematics, p. 65. doi: $10.1145 / 1134285.1134500$.

[6] Slaev, A.D. \& Nedovic-Budic, Z. 2017. The challenges of implementing sustainable development: The case of Sofia's master plan. Sustainability (Switzerland), 9(1) pp. 1-19. doi: 10.3390/su9010015.

[7] Moroke, T., Schoeman, C. \& Schoeman, I. 2019. Developing a neighbourhood sustainability assessment model: An approach to sustainable urban development. Sustainable Cities and Society, January 2018, p. 101433. doi: 10.1016/j.scs.2019.101433.

[8] Kaagaard, L.M.K. 2016. Planning for sustainability. Management of Creative Business Processes, March 2016, 1.

[9] Endo, T. \& Shibuya, M.K. 2017. Urban risk, risk response and well-being in Asian cities: The case of Tokyo, Shanghai, and Bangkok. Procedia Engineering, 198(September), pp. 975-984. doi: 10.1016/j.proeng.2017.07.143.

[10] Wamsler, C., Brink, E. \& Rivera, C. 2013. Planning for climate change in urban areas: From theory to practice. Journal of Cleaner Production, 50, pp. 68-81. doi: 10.1016/j.jclepro.2012.12.008.

[11] Laffta, S. \& Al-Rawi, A. 2018. Green technologies in sustainable urban planning. MATEC Web of Conferences, 162, 2018, pp. 1-7.

[12] Shabatura, L., Bauer, N. \& latsevich, O. 2018. Socio-cultural problems of sustainable urban environment. IOP Conference Series: Materials Science and Engineering, 2018. doi: 10.1088/1757-899X/463/2/022009.

[13] Habibi, S. \& Zebardast, E. 2016. How compact are midsize cities in Iran?, Journal of urban planning and development, 142(4), 2016, pp. 1-11. doi: 10.1061/(ASCE)UP.1943-5444.0000333.

[14] Russo, T., Alfredo, K. \& Fisher, J. 2014. Sustainable water management in urban, agricultural, and natural systems. Water (Switzerland), 6(12), pp. 3934-3956. doi: 10.3390/w6123934.

[15] Randhawa, A. \& Kumar, A. 2017. Exploring sustainability of smart development initiatives in India. International Journal of Sustainable Built Environment, 6(2), pp. 701-710. doi: 10.1016/j.ijsbe.2017.08.002.

[16] Chang, I.C. \& Sheppard, E. 2013. China's eco-cities as variegated urban sustainability: Dongtan eco-city and Chongming. Journal of Urban Technology, 12(2) pp 57-75. doi: 10.1080/10630732.2012.735104.

[17] Currie, P.K. \& Musango, J.K. 2016. African urbanization assimilating urban metabolism into sustainability discourse. Journal of Industrial Ecology, 21(5), pp 1262-1276. doi: 10.1111/jiec.12517.

[18] Battersby, J. 2017. System transformation in food in the absence of food system planning: The case of supermarket and shopping mall retail expansion in Cape Town, South Africa. Built Environment, 43(3), pp. 417-430. doi: 10.2148/benv.43.3.417

[19] Ding, X., Zhong, W., Shearmur, R.G., Zhang, X. \& Huisingh, D. 2015. An inclusive model for assessing the sustainability of cities in developing countries - Trinity of Cities' Sustainability from Spatial, Logical and Time Dimensions (TCS-SLTD). Journal of Cleaner Production, 109, pp. 62-75. doi: 10.1016/j.jclepro.2015.06.140.

[20] Bai, M., Zhou, S., Zhao, M. \& Yu, J. 2017. Water use efficiency improvement against a backdrop of expanding city agglomeration in developing countries: A case study on industrial and agricultural water use in the Bohai Bay Region. Water (Switzerland), 9(2). doi: 10.3390/w9020089.

[21] Simon, D. 2013. Climate and environmental change and the potential for greening African cities. Local Economy, 28(2), pp 203-217. doi: 10.1177/0269094212463674.

[22] Horn, A. 2015. Urban growth management best practices: Towards implications for the developing world. International Planning Studies, 20, pp. 131-145. doi: 10.1080/13563475.2014.942513. 
[23] Babalik-Sutcliffe, E. 2013. Urban form and sustainable transport: Lessons from the Ankara case urban form and sustainable transport. International Journal of Sustainable Transportation, 7(5), pp 416-430. doi: 10.1080/15568318.2012.676152.

[24] Zhang, X. 2016. Sustainable urbanization: A bi-dimensional matrix model. Journal of Cleaner Production, 134, pp. 425-433. doi: 10.1016/j.jclepro.2015.08.036.

[25] Brelsford, C., Lobo, J., Hand, J. \& Benttencourt, L.M.A. 2017. Heterogeneity and scale of sustainable development in cities. Proceedings of the National Academy of Sciences of the United States of America, 114(34), pp 8963-8968. doi: 10.1073/pnas.1606033114.

[26] Musango, J.K. 2014. Energy for sustainable development: Household electricity access and consumption behaviour in an urban environment: The case of Gauteng in South Africa. Energy for Sustainable Development, 23, pp. 305-316. doi: 10.1016/j.esd.2014.06.003.

[27] Xu, Y., Ren, C., Ma, P., Ho, J., Wang, W., Lau, K.K.L., Lin, H. \& Ng, E. 2017. Landscape and urban planning: Urban morphology detection and computation for urban climate research. Landscape and Urban Planning, 167(May), pp. 212-224. doi: 10.1016/j.landurbplan.2017.06.018.

[28] Broto, V.C. 2017. Energy landscapes and urban trajectories towards sustainability. Energy Policy, 108(January), pp. 755-764. doi: 10.1016/j.enpol.2017.01.009.

[29] Dur, F., Yigitcanlar, T. \& Bunker, J. 2014. A spatial-indexing model for measuring neighbourhood-level land-use and transport integration. Environment and Planning B: Planning and Design, 41(5), pp. $792-812$. doi: $10.1068 / b 39028$.

[30] Ahmed, K.G. 2017. Designing sustainable urban social housing in the United Arab Emirates. Sustainability (Switzerland), 9(8). doi: 10.3390/su9081413.

[31] Artmann, M., Kohler, M., Meinel, G., Gan, J. \& loja, I. 2019. How smart growth and green infrastructure can mutually support each other: A conceptual framework for compact and green cities. Ecological Indicators, 96(June), pp. 10-22. doi: 10.1016/j.ecolind.2017.07.001.

[32] Aburas, M.M., Ho, Y.M., Ramli, M.F. \& Ash'aari, Z.H. 2018. Monitoring and assessment of urban growth patterns using spatio-temporal built-up area analysis. Environmental Monitoring and Assessment, 190(3). doi: 10.1007/s10661-018-6522-9.

[33] Li, W., Zhou, W., Han, L. \& Qian, Y. 2019. Uneven urban-region sprawl of China's megaregions and the spatial relevancy in a multi-scale approach. Ecological Indicators, 97(December), pp. 194-203. doi: 10.1016/j.ecolind.2018.10.004. 